\title{
A Jacobite chronology
}

Until 1707 all the monarchs and putative monarchs of the three kingdoms had different titles in England and Scotland (Ireland followed English practice); thus William of Orange became William III in England and William II in Scotland. Purely for the sake of brevity, however, the chronology below identifies monarchs by their English/British title, viz. James II, rather than James II and VII.

\section{8}

10 June

Birth of James Francis Edward Stuart, Prince of Wales

5 November Dutch Stadthouder Prince William of Orange lands at Torbay with a Dutch army

13 November- English army and James II progressively

9 December demoralised by defections of officers and men to William of Orange

10 December Queen Mary of Modena escapes to France with the Prince of Wales; James II orders LieutenantGeneral the Earl of Feversham to disband the English army, throws the Great Seal in the Thames and flees London

11 December James II arrested by a group of Kentish fishermen on Isle of Sheppey while trying to escape to France

15 December James II escorted back to London amid great celebration

18 December William of Orange orders James II be moved to Rochester

23 December James II escapes to France 
1689

28 January

13 February

12 March

25 March

18 April

1 May

5 May

7 May

18 May

17 July

28 July

13 August

21 August

1690

1 February

1 May
House of Commons declares James II to have abdicated the throne by his flight

William of Orange and Princess Mary accept offer of crown from English Parliament; accede as joint monarchs William III and Mary II James II lands at Kinsale in Ireland with 5,000 French troops

Scottish Convention declares the throne 'forfaulted' and offers the crown to William and Mary

James II fired on by the defenders of Derry/ Londonderry; formal siege of city begins Royal Navy squadron under Admiral Herbert defeated in Bantry Bay by Admiral ChateauRenault's French squadron England declares war on France

Revanchist, overwhelmingly Catholic, 'Patriot Parliament' meets in Dublin Viscount Dundee musters Jacobite clans at Lochaber and launches the Highland War Dundee routs Major-General Mackay's Williamites at Killiecrankie, but is killed in process

Royal Navy convoy breaks through to relieve the starving defenders of Derry/Londonderry Lieutenant-General the Duke of Schomberg and a Williamite army land at Carrickfergus Major-General Cannon's Scots Jacobite army repulsed by Lieutenant-Colonel Cleland's Cameronians at Dunkeld

Over 400 Anglican clergy (including 5 bishops) deprived for refusing the oaths to William and Mary; beginning of Nonjuror schism Major-General Buchan's Scots Jacobite army routed at the Haughs of Cromdale; guerilla war commences in Highlands 
7 June

30 June

1 July

3 July

30 August

1691

1 January

30 June

12 July

23 August

3 October

2 December

\section{2}

January

13 February

19-20 May

18 June
Presbyterianism officially re-established in Scotland; beginning of Scots Episcopalian schism Anglo-Dutch fleet commanded by Admiral Torrington defeated off Beachy Head by French fleet under Admiral Tourville William III defeats James II at the battle of the Boyne

James II leaves Ireland for France William III forced to raise first siege of Limerick and retreat to Dublin

Viscount Preston captured en route to St Germain; subsequently reveals details of Jacobite plotting

Earl of Breadalbane negotiates truce in Highland War while Jacobite clans seek James II's permission to negotiate surrender Lieutenant-General Ginkel's Williamite army defeats French and Jacobites under LieutenantGeneral St Ruth at Aughrim

Ginkel's army commences second siege of Limerick

Limerick surrenders on generous terms; most of garrison and other remnants of the Irish Jacobite army opt to be evacuated to France James II gives Scots Jacobite clans permission to surrender

Jacobite clans surrender to the government Massacre of Macdonalds of Glencoe Anglo-Dutch fleet under Admiral Russell scatters French fleet under Tourville at Barfleur; subsequently corners and burns French stragglers at La Hogue (23-4 May); planned FrancoJacobite invasion of England abandoned Birth of Princess Louisa Maria Theresa ('la consolatrix') 
1693

ca.1 April Earl of Middleton arrives in France to take up position as Jacobite co-Secretary of State with

7 April Earl of Melfort and Lord Caryll James II issues conciliatory, Protestant-oriented manifesto

1694

16 May

17-22 October Eight prominent Lancashire Catholics acquitted of Jacobite conspiracy (the 'Lancashire plot')

1695

October

Preparations begin for coordinated French invasion and Jacobite rising known as 'Fenwick' plot

1696

January

15 February Authorities alerted to Jacobite conspiracy by 'Assassination' plot informers

22 February Mass arrests of Jacobite conspirators begin March-April Seven Jacobite conspirators tried and executed; five more condemned to life imprisonment without trial by Act of Parliament

ca.1 May French invasion plan abandoned

ca. June Onset of four years of famine in Scotland ('King William's ill years')

23 December Sir John Fenwick condemned to death by Act of Attainder

\section{7}

10 September Peace of Ryswick; Louis XIV recognises William III as king of the three kingdoms; James II spurns secret offer by William III to raise Prince of Wales as his heir 
1700

30 July

ca. August

1701

17 February

24 April

May-

September

6 September

November

1701-

January 1702

1702

7 March

8 March

15 May

July

August

1703

May-October Returning to Scotland, Lovat concocts fake ('Scotch') plot in Highlands; Captains Moray and Murray meanwhile negotiate real plan for an uprising with Scots Jacobite leaders 
1704

17 January

11 June

3 August

1705

27 July

August

7 September

6 October

December

1706

12 May

October-

December

1707

April-May

10 April

1 May

6 June

28 June

12 October
Lovat, back in France, sent to the Bastille for his role in the 'Scotch' plot

Middleton proposes invasion of British Isles to Louis XIV

Prince Eugène and the Duke of Marlborough decisively defeat the Franco-Bavarian army under Maréchal Tallard at Blenheim

Louis XIV's emissary, Colonel Hooke, arrives in Scotland

Hooke negotiates with the Jacobite 'Juncto' and reconnoitres Scotland to assess seriousness of Jacobite pledges of support

Hooke sails for France with pledges to rise Hooke's first report on Scotland submitted to French Conseil d'en Haut

French invasion plan shelved pending arrival of emissary from the Juncto

Marlborough decisively defeats Maréchal Villeroi at Ramillies; Scots invasion indefinitely postponed

Passage of Act of Union in Scotland; Jacobites plan uprising but are let down by Duke of Hamilton

Hooke negotiates with the Jacobite Juncto on terms for a rising in Scotland

Hooke arrives in Scotland on his second mission from Louis XIV

Union of England and Scotland comes into force Hooke arrives back in France

Hooke's second report on Scotland submitted to the French Conseil d'en Haut

Scots Jacobites advised by France to prepare for an invasion and rising in Spring 1708 
1708

15 February Dutch government sends Queen Anne first clear warning of coming invasion attempt

27 February James arrives at Dunkirk but comes down with measles; Royal Navy squadron under Admiral Byng arrives off Dunkirk same day

6 March

12 March

15 March

Mid-April

30 June

1709

April

31 August

1710

27 February20 March

September
Admiral the Comte de Forbin's invasion fleet successfully evades Royal Navy blockade and sails for Scotland Invasion fleet arrives in Firth of Forth, but too late in day to land. Next morning sights Byng's squadron and flees north

Adverse winds prevent Forbin's fleet entering Moray Firth to land at Inverness; council of war decides to return to Dunkirk

Last of Forbin's separated and scattered ships arrive back in France of Burgundy and Maréchal Vendôme at Oudenarde; James serves as a volunteer on Burgundy's staff

James directs Jacobites in British Isles to suspend further plotting and preserve themselves for future opportunities

Eugène and Marlborough win Pyrrhic victory over Marshal Villars at Malplaquet; James wounded while serving as volunteer with French cavalry

Impeachment of High Church divine, Henry Sacheverell, by Whig government polarises British politics and provokes serious rioting in London and across England Earl of Jersey, secretly negotiating terms of a separate peace with French agent the Abbé Gaultier on behalf of new ministry led by Robert
Eugène and Marlborough defeat the Duke 
Xxii

September-

October

1711

January

26 August

27 September

October-

November

\section{2}

August

18 August

15 November

\section{3}

18 February

3 May

AugustSeptember

13 December

24-28

December
A Jacobite chronology

Harley, states it is willing to restore James after death of Queen Anne Ca. 332 Tories (including ca. 40 Jacobites) are returned in electoral landslide precipitated by Sacheverell impeachment

High Tory and Jacobite 'October Club' of militant backbenchers makes its first appearance in the Commons

James orders Jacobites in Parliament to support Harley (now Oxford) ministry

Preliminary articles for a (separate) peace with France made public by the Oxford ministry Elector of Hanover (the future George I) makes clear his displeasure at Oxford ministry negotiations with France

James denies permission for formation of a breakaway group of Jacobite Tory M.P.s in Commons; directs them to continue supporting Oxford ministry

Princess Louisa dies of smallpox at St Germain The most prominent Scots Jacobite, the Duke of Hamilton, killed in a duel with Whig Lord Mohun

As part of peace settlement James leaves France for Lorraine Oxford requests James order his followers in Britain to support the ministry in the upcoming election; James agrees Tories and Jacobites win massive victory at general election (363 seats) Middleton resigns as Jacobite Secretary of State; nominally replaced by Sir Thomas Higgons, actually by Duke of Berwick Queen Anne briefly, but seriously, ill 
1714

15 January

6 February

2 March

21 June

22 Juneca. 4 July

27 July

1 August

10 August

October

20 October

1715

22 January-

9 March

27 March

June-August

12-21 June

10 July

12 July
Oxford demands James convert to Protestantism before he will seek to restore him Oxford's rival for Tory leadership, Viscount Bolingbroke, independently demands James's conversion as a prerequisite for action James refuses to contemplate conversion Cabinet agrees to post reward of $£ 5,000$ (subsequently increased by vote in Commons to $£ 100,000$ ) for apprehension of James in the event of his landing in Britain

Jacobite M.P.s begin harrassing ministerial supply bills; ca. 5 July Bolingbroke promises them he will work to restore James; Jacobite obstruction of supply ceases

Oxford dismissed by Queen Anne; Bolingbroke triumphant

Queen Anne dies; George I peacefully proclaimed throughout British Isles

James arrives incognito in Paris seeking French help; Louis XIV sends him back to Lorraine Wave of High Tory rioting against Dissenters sweeps Midlands and southern England

George I crowned

General election; Whigs win crushing electoral victory

Bolingbroke flees to France

Intense wave of pro-Jacobite rioting sweeps

Midlands and north of England

Oxford, Bolingbroke, Ormonde and Strafford impeached

Convinced the time is ripe, James secretly sets out for Britain and gets as far as Paris, but is there persuaded reluctantly to return to Lorraine while Jacobites in Britain make further preparations

Bolingbroke appointed Jacobite Secretary of State 
xxiv

8 August

9 August

21 August

6 September

8 September

17 September

6 October

11 October

12-13 October

17 October

19 October

22 October

28 October

2 November

6 November

7 November

9-10 November

12 November
Ormonde arrives in Paris, having fled England Earl of Mar leaves London for Scotland; arrives 16 August and retires to the Highlands

Death of Louis XIV; Duke of Orléans becomes Regent

Mar raises Jacobite standard at Braemar and Kirkmichael; local risings all over Scotland follow over rest of month Thomas Arthur leads unsuccessful attempt to seize Edinburgh castle John Hay of Cromlix captures Perth for the Jacobites; Mar establishes Jacobite HQ there 28 September

Thomas Forster M.P. and the Earl of

Derwentwater proclaim James on Waterfalls Hill in Northumberland

Viscount Kenmuir musters Borders Jacobites at Moffat

William Macintosh of Borlum's force crosses the Firth of Forth

James sets out secretly for French coast from

Lorraine pursued by British agents

Kenmuir and Forster link up at Rothbury

Borlum reaches Kelso and links up with Forster and Kenmuir

Failing to receive the expected signals,

Ormonde abandons attempt to land in West

Country and sails back to France; James arrives at St Malo

Forster et al. take Penrith, routing possecomitatus en route

James embarks, but encounters storm and is forced back into St Malo; waits in vain for a month for a favourable wind

Forster reaches Lancaster; flow of Jacobite recruits steps up

Forster marches into Preston; Mar marches south from Perth

Major-General Wills attempts to storm Preston and is bloodily repulsed; Mar advances towards 
Dunblane; Lieutenant-General the Duke of Argyll advances from Stirling onto Sheriffmuir

13 November Forster's Jacobites repulse another attack at Preston, but Lieutenant-General Carpenter reinforces Wills and Forster decides to surrender; Mar and Argyll fight drawn battle at Sheriffmuir

14 November Forster's army surrenders; Mar retreats to Perth 16 December James embarks at Dunkirk with a favourable wind

22 December James lands at Peterhead, near Aberdeen

1716

31 January James retreats from Perth in the face of Argyll's advance northwards

4 February James and Mar sail from Montrose for France

c. 12 February James dismisses Bolingbroke

15 February Remnant of Jacobite army disperses at Ruthven in Badenoch

11 March

Mar appointed Jacobite Secretary of State

23 March

June-July

James expelled from France; retreats to papal enclave at Avignon

Fighting in London between Jacobites and Whig 'Mug-house' gangs

August

Renewed Jacobite negotiations with Sweden for an invasion (the 'Swedish' plot) commence at Paris

17 November Franco-British alliance signed

1717

26 January

James forced to leave Avignon by French government

29 January Swedish Ambassador in London arrested and his papers seized; 'Swedish' plot aborted

9 March James reaches Pesaro and temporarily takes up residence there

June 1717- Ormonde negotiations with Peter the Great

March 1718

30 June

July

James moves Jacobite court to Urbino Indemnity Act passes in Parliament; allows many 
exiled Jacobites and others not yet condemned by the courts to return home

1718

28 April

11 July

11 August

22 September

October

6 December

1719

27 January

24 February

25 February

13 March

18 March

9 April

16/17 April

5 June

21 August

21 October

\section{Death of Queen Mary of Modena}

Marriage contract between James and Princess Clementina Sobieska signed at Ohlau

Anglo-Dutch fleet decisively defeats Spanish fleet off Cape Passaro

Clementina, on her way to marry James, arrested at Innsbruck by order of Emperor Charles VI (at behest of George I)

Preparations for a Spanish invasion of England, supported by a Jacobite rising, commence Britain, as part of the Quadruple Alliance, declares war on Spain

James leaves for Spain

Main Spanish invasion force (aimed at England) sails from Cadiz

Secondary Spanish invasion force under the Earl Marischal (aimed at Scotland) sails from Los Pasajes

Mar resigns as Jacobite Secretary of State; replaced by Acting Secretary James Murray of Stormont

Main Spanish expedition dispersed by storm; invasion of England abandoned

Marischal and two ships reach Lewis; 1719 rising begins in Scotland

Clementina rescued from Innsbruck by squad of Irish officers led by Captain Charles Wogan Marischal and Scots Jacobite army defeated at Glenshiel by a force under Major-General Wightman

James marries Princess Clementina at Montefiascone

James and Clementina take up residence in the Palazzo del Re in Rome 
1720

February- $\quad$ South Sea Bubble financial crisis in London ruins August

6 February

20 December

1721

26 January

October thousands

Treaty of the Hague ends the War of the

Quadruple Alliance; Spain renounces alliance with James
James dismisses Murray as Acting Secretary of State; replaced by John Hay of Cromlix Genesis of conspiracy known as the 'Atterbury' plot after lead conspirator, Francis Atterbury, Bishop of Rochester

\section{2}

May-September Atterbury plot betrayed; ministry systematically arrests most of the plotters

27 November Christopher Layer convicted of treason

1723

6-15 May

17 May

18 June

October

21 November

1725

28 January

22 February

23 February

29 April

4 November
Bill of pains and penalties passed against Atterbury Layer executed Atterbury leaves England for exile in France Renewed Jacobite negotiations with Peter the Great

Death of Regent Orléans

Death of Peter the Great; Jacobite negotiations, however, continue with Tsarina Catherine I Hay appointed Jacobite Secretary of State and publicly avowed as Jacobite Earl of Inverness Birth of Henry Benedict Stuart, Jacobite Duke of York

Alliance of Vienna between Habsburgs and Spain

Clementina withdraws to a convent demanding dismissal of Inverness 
1726

26 June

21 September
Rising tension between Britain and Spain provokes British naval blockade of Porto Bello Confronted by papal support for Clementina, James and Jacobite court withdraw from Rome to Bologna; Clementina remains behind in convent

\section{7}

31 January

23 March

1 June

11 June

24 June

26 June

31 July

30 December

1728

30 September Graeme resigns as Jacobite Secretary of State;

1729

26 January

23 February

1730

11 January James instructs the Jacobites in Parliament to

December Atterbury refuses to replace him and James henceforth acts without a Secretary of State unite with any other opponents of ministry to bring down Prime Minister Sir Robert Walpole

Spain commences siege of Gibraltar Inverness resigns and Jacobite knight Sir John Graeme replaces him as Secretary of State Spanish forces abandon siege of Gibraltar Death of George I; George II succeeds peacefully On hearing of George I's death James gallops (almost alone and incognito) to Lorraine in hope of joining a Scots rising

Clementina emerges from convent and goes to Bologna

James obliged to quit Lorraine for Avignon James returns to Bologna

James returns to Rome, followed by Clementina and the Jacobite court in April-May Convention of the Pardo brings Spanish-British hostilities to an end Inverness returns to Jacobite court 
1731

January

22 July

\section{3}

March-May Excise Crisis threatens to bring down the

June

30 September

October-

November

\section{4}

4-6 August

\section{5}

7 January

30 January

\section{6}

7 September Captain William Porteous lynched by mob in Edinburgh for having fired on the crowd attending the execution of a smuggler; Edinburgh is subsequently punished, heightening public outrage vs the government

\section{8}

6 January Walpole ministry

Viscount Cornbury, on a visit to Rome, first contacts Jacobite court

Second treaty of Vienna between Britain and Habsburgs signals virtual end of Anglo-French alliance

Cornbury plotters ask France to invade Britain

France declares war on Habsburgs and Saxony; beginning of the War of the Polish Succession. Britain stays neutral and becomes diplomatically isolated

Cornbury plot peters out due to French lack of interest

Charles Edward attracts positive attention by his active participation in the siege of Gaeta by Spanish army

Death of Queen Clementina James requests that the Archbishop of Paris consider the evidence of miracles associated with James II with a view to his canonisation 
Edward to Scotland with or without foreign support

1739

19 October Britain declares war on Spain

December William Macgregor of Balhaldy sent to Rome on behalf of the Scots Jacobite 'Associators'; urges James to seek French help for a rising

1740

May

Earl of Barrymore visits Paris on behalf of English Jacobite Tory leadership to urge French to invade Britain and restore Stuarts; Cardinal Fleury refuses

5 December Frederick the Great invades Silesia, sparking War of Austrian Succession

1741

13 March Scots Jacobite 'Associators' formally write to Cardinal Fleury requesting a French invasion; Fleury defers decision

30 April-

11 June General election leaves Walpole ministry with

16 September James instructs Jacobites in Parliament to cooperate with dissident Whigs to bring down Walpole

\section{2}

6 February

After weeks struggling against revitalised opposition Walpole resigns

March Tories once more refused public office by George II; Pulteney Whigs abandon them to join existing Whig ministry (the 'Old Corps')

\section{3}

18 January Death of Cardinal Fleury; Louis XV decides to act as his own principal minister

May Leading Welsh Jacobite Sir Watkin Williams Wynn has personal audience with Louis XV and asks for a French invasion 
August-October French agent, Captain James Butler, scouts English Jacobite support for a French invasion and submits positive report on his return to France

29 November Louis XV commits himself to invade England; French preparations for surprise attack initially scheduled for 29 December begin

30 December Charles Edward commences secret journey to France

1744

January

14 February British government discovers plot; mass arrests follow

23-24 February Hurricane drives French fleet (there to escort invasion to Essex) back into Brest and wrecks French troop transport ships at Dunkirk

28 February Louis XV shelves invasion of England August Charles Edward begins secret preparations for an unsupported invasion and rising in Scotland

1745

30 April

Marshal Saxe defeats Captain-General the Duke of Cumberland's Anglo-Dutch army at Fontenoy

5 July

9 July Charles Edward sets sail from Nantes in frigate Du Teillay escorted by warship Elisabeth carrying troops and munitions Charles Edward intercepted by HMS Lyon; Elisabeth badly damaged and forced to return to France

23 July Charles Edward lands on Eriskay

19 August Jacobite standard raised at Glenfinnan

17 September Jacobite army captures Edinburgh

21 September Jacobites under Lord George Murray rout Lieutenant-General Sir John Cope's government army at Prestonpans

3 October Louis XV orders invasion of England in support of Charles Edward

8 November Jacobite army enters England on march south 
26 November Lord John Drummond and an expeditionary force of French troops land at Montrose

5 December In council at Derby senior Jacobite officers insist on army turning back

20 December Jacobite army re-enters Scotland

23 December Norman Macleod of Dunvegan and government force routed at Inverurie by French and Jacobites under Lord Lewis Gordon

23-25 December French invasion fleet under Lieutenant-General the Duc de Richelieu at Boulogne is bottled up by Royal Navy and unable to get out of harbour

1746

17 January Jacobites under Lord George Murray defeat Lieutenant-General Hawley's government army at Falkirk

1 February French invasion cancelled and forces redeployed; Jacobite army abandons siege of Stirling castle and begins retreat to north-east Scotland 5 March Fort Augustus surrenders to Jacobite besiegers 16-31 March Lord George Murray and a Jacobite force raid Atholl, but siege of Blair Atholl castle fails

20 March- Unsuccessful Jacobite siege of Fort William 3 April

April-September Cumberland's army harries Highlands and hunts for fugitive Charles Edward

16 April Jacobites under Charles Edward defeated at Culloden by government army under Cumberland

17-20 April Jacobite army rallies at Ruthven; only disperses on orders from Charles Edward

8 May Secretly meeting at Mhurlagain, Donald Cameron of Lochiel and chieftains of Macdonalds of Glengarry, Clanranald and Keppoch and Stuarts of Appin agree to remuster their forces and fight on

21-22 May Lochiel and his clansmen muster as agreed at Achnacarry, but none of the other clan chiefs appear; Lochiel orders his clansmen to disperse 
and goes into hiding pending escaping to France; end of the ' 45

30 September Charles Edward arrives back in France

8-22 October Charles Edward lionised by Louis XV and French court

November Charles Edward asks Louis XV for 20,000 men for an invasion of England

December Louis XV offers 6,000 men for an invasion of Scotland; Charles Edward refuses

1747

14 Januaryend February April

19 April

22 June

22-29

September

1748

14 August

18 October

30 November

3 December

16 December
Charles Edward journeys to Madrid and unsuccessfully solicits Spanish support Lochiel and other exiled chieftains ask Louis $\mathrm{XV}$ to send them and the expedition offered to Charles Edward to Scotland with or without the prince

Henry Benedict flees Charles Edward; returns to Rome

Henry Benedict takes holy orders and is raised to Cardinalate

Jacobite demonstrations at Lichfield races
Louis XV asks Charles Edward to leave France so as to facilitate peace negotiations between France and Britain; the prince refuses

Peace of Aix-la-Chapelle ends War of Austrian Succession Charles Edward publicly defies Louis XV by attending the Comédie Française in Paris; he is abducted that night on Louis XV's orders and incarcerated at Vincennes

Charles Edward released on condition he leave France

Charles Edward arrives in Avignon 
14 February Charles Edward departs from Avignon to begin peripatetic, disguised existence secretly moving around western Europe for the next seventeen years

1750

May-July Sustained Jacobite rioting in and around Walsall 5-12 September Charles Edward visits London to consult with English Jacobite leaders; while there formally converts to Anglicanism

1751

February Frederick the Great secretly meets Charles Edward in Berlin; genesis of 'Elibank' plot

1752

May

14 May

10-12 June

8 November

Charles Edward resumes relationship with Clementina Walkinshaw despite English Jacobite objections

Assassination of Duke of Argyll's agent Colin Campbell of Glenure (the 'Appin Murder') allegedly by Ailean Breac Stewart Jacobite riots in Exeter Execution of James Stewart for complicity in the assassination of Glenure

\section{3}

March

'Elibank' plot betrayed; Archibald Cameron captured preparing revolt in Highlands

7 June Cameron executed - last man to die for Jacobite cause

29 October Birth of Charlotte, Charles Edward's daughter by Clementina Walkinshaw

1754

April

After acrimonious row between Marischal and Charles Edward, the English Jacobites suspend relations with the prince

9 July Defeat of a British force under Major-General 
Braddock at the battle of the Monongahela by French and Indian troops under Captain Beaujeu begins a slide into war between Britain and France

1756

17 May

29 August

Britain formally declares war on France Prussia invades Saxony, triggering Europeanwide 'Seven Years' War'; Franco-British conflict merges with the larger war

1759

1 January

Sir Alexander Mackenzie Douglas of Kildin proposes invasion of England to Conseil d'en Haut

5 February Charles Edward meets French premier minister the Duc de Choiseul to discuss projected invasion of England; Choiseul disgusted by his drunken obstinacy but continues preparations 20 November Royal Navy squadron under Admiral Hawke decisively defeats French fleet under Admiral Conflans at Quiberon Bay, aborting planned invasion

1760

22 July

25 October

Clementina Walkinshaw flees Charles Edward's drunken violence, taking her daughter with her Death of George II; popular, assertively British grandson, George III, peacefully succeeds him

1763

10 February Treaty of Paris ends Britain's participation in Seven Years' War

\section{6}

1 January

14 January

Death of James III and VIII in the Jacobite line Pope Clement XIII formally refuses to acknowledge Charles Edward as King Charles III. The other great powers follow suit 
xxxvi

1772

17 April

1774

October

1780

9 December Louise flees to a convent to escape Charles Edward's alcoholic violence

1783

December

1784

June

1785

December

1788

30 January
With secret encouragement from France Charles Edward marries Louise von Stolberg

Jacobite court moves to Florence
Edward's alcoholic violence

Gustav III of Sweden stays with Charles Edward in Florence

Charles Edward summons his daughter Charlotte to court, creates her Jacobite Duchess of Albany and formally recognises and legitimises her

Jacobite court returns to Rome

Death of Charles Edward; Cardinal Henry Benedict privately assumes title 'Henry IX and I'; Scots Episcopalian church refuses to recognise him as king and transfers allegiance to George III

1789

17 November Death of Charlotte Stuart, Jacobite Duchess of Albany

$1804 \quad$ Last known meeting of a Nonjuring congregation (in Manchester)

1807

13 July

Death of Henry Benedict, last direct heir of James II and VII 